\title{
Elena Del Panta, “L'histoire que je vais vous raconter...". Figure del narratore nella «Comédie humaine»
}

Marco Stupazzoni

\section{OpenEdition}

1 Journals

\section{Edizione digitale}

URL: https://journals.openedition.org/studifrancesi/39598

DOI: $10.4000 /$ studifrancesi.39598

ISSN: 2421-5856

\section{Editore}

Rosenberg \& Sellier

\section{Edizione cartacea}

Data di pubblicazione: 1 décembre 2004

Paginazione: 391-392

ISSN: 0039-2944

\section{Notizia bibliografica digitale}

Marco Stupazzoni, «Elena Del Panta, "L'histoire que je vais vous raconter...". Figure del narratore nella «Comédie humaine»», Studi Francesi [Online], 143 (XLVIII | II) | 2004, online dal 30 novembre 2015, consultato il 19 mai 2021. URL: http://journals.openedition.org/studifrancesi/39598 ; DOI: https:// doi.org/10.4000/studifrancesi.39598

Questo documento è stato generato automaticamente il 19 mai 2021.

\section{cc) $(9)$}

Studi Francesi è distribuita con Licenza Creative Commons Attribuzione - Non commerciale - Non opere derivate 4.0 Internazionale. 


\title{
Elena Del Panta, “L'histoire que je vais vous raconter...". Figure del narratore nella «Comédie humaine»
}

\author{
Marco Stupazzoni
}

\section{NOTIZIA}

ELENA DEL PANTA, “L'histoire que je vais vous raconter...". Figure del narratore nella "Comédie humaine», «Rivista di Letterature moderne e comparate», vol. LV, nuova serie, Fasc. 4 , ottobre-dicembre 2002, pp. 413-431.

1 Tra le cosiddette opere della maturità balzachiana, v'è un racconto, Autre étude de femme, di cui già Proust, nel suo Contre Sainte-Beuve, evidenziava l'importanza per l'innumerevole e sorprendente concentrazioni di attori (di voci narranti) su un palcoscenico narrativo abbastanza ristretto. Il testo si struttura infatti in cinque situazioni di comunicazione, coordinate di volta in volta tra loro da un personaggio diverso su cui tutti gli altri concentrano il loro sguardo e la loro attenzione.

2 Così come, in alcune prefazioni ai romanzi della Comédie humaine, Balzac aveva utilizzato la figura di Rastignac per concentrare un insieme di personaggi e di romanzi in un reticolo di rapporti che vedeva l'eroe parigino in una posizione privilegiata rispetto agli altri, nel salotto di Mlle des Touches ogni personaggio ricompone la dispersione caotica degli invitati intorno al proprio discorso, provocando le loro reazioni e generando altre storie, altri 'récits'.

3 Le diverse tipologie della scrittura e della narrazione si presentano, dunque, all'interno dell'opera di Balzac, come estremamente variegate e dinamiche, sfuggendo costantemente alla rigidità e alla univocità interpretative.

4 In questo studio, Elena Del Panta illustra in maniera convincente, avvalendosi di numerosi riferimenti testuali significativi tratti da varî racconti balzachiani, quali Sarrasine, Une passion dans le désert, Facino Cane, La Maison Nucingen, Autre Étude de femme 
e Z. Marcas, alcune importanti modalità di restituzione finzionale dell'io narrante, o, in altri termini, del binomio 'auteur/narrateur', cogliendo, "come in un fermoimmagine», $i$ luoghi in cui questa figura bifronte «lascia prevalere l'una o l'altra parte di sé» e quelli in cui si ri-compone «nell'entità metastorica identificabile per convenzione in un 'Balzac' assurto a figura di 'Autore'«(p. 414). 